Pengembangan Lembar Kegiatan Peserta Didik Berbasis Problem Based Lerning... Vol. 7 No. 3 Tahun 2019

\title{
Pengembangan Lembar Kegiatan Peserta Didik (LKPD) Berbasis Problem Based Learning dan Berpikir Kritis pada Materi Ekonomi Kelas XI
}

\section{Cynthia Eka Putri}

Program Studi Pendidikan Ekonomi, Fakultas Ekonomi, Universitas Negeri Surabaya email: cynthiaputri@mhs.unesa.ac.id

\section{Dhiah Fitrayati}

Program Studi Pendidikan Ekonomi, Fakultas Ekonomi, Universitas Negeri Surabaya email : dhiahfitrayati@unesa.ac.id

\begin{abstract}
Abstrak
Tujuan dari penelitian pengembangan LKPD berbasis Problem Based Learning (PBL) dan Berfikir Kritis untuk menganalisis (1) kelayakan dari pengembangan LKPD, (2) efektifitas dari pengembangan LKPD, (3) respon peserta didik terhadap pengembangan LKPD. Jenis pengembangan mengaplikasikan penelitian dan pengembangan atau Research and Development (R\&D) dengan memilih model pengembangan 4-D Thiagarajan yang terdiri dari define, desain, development, dan dissemination. Penelitian pengembangan ini dilaksanakan hingga tahap yang ke ketiga yaitu Develop hingga pada tahap mengetahui kelayakan dan efektivitas pengembangan LKPD. Pengumpulan data diperoleh dari hasil validasi kelayakan LKPD dari kegiatan pretest dan posttest, dan hasil respon siswa terhadap penerapan LKPD yang telah dilakukan. Hasil observasi yang telah dilakukan menunjukan bahwa (1) rata-rata hasil validasi kelayakan materi bernilai sebesar $83 \%$, sedangkan untuk rata-rata hasil validasi kelayakan kegrafikan bernilai nilai sebesar 93\%, dan rata-rata hasil validasi kelayakan Bahasa bernilai sebesar $80 \%$. (2) hasil efektivitas yang yang dilhat dari kegiatan pretest dan posttest memperoleh hasil ketuntasan dari 8\% naik menjadi $81 \%$ dengan hasil $\mathrm{N}$-Gain sebesar 0,81 yang termasuk dalam kategori tinggi (3) berdasarkan angket respon siswa yang sudah diberikan menunjukkan presentase sebesar $84 \%$. Hal ini menunjukkan bahwa pengembangan LKPD berbasis Problem Based Learning dan Berfikir Kritis pada Materi Ekonomi Kelas XI sangat layak digunakan.
\end{abstract}

Kata Kunci: Lembar Kegiatan Peserta Didik, Problem Based Learning, dan Berpikir Kritis

Abstract

The purpose of the research Development Of LKPD On Problem Based Learning And Critical Thinking are to analyze (1) The feasibility of developing LKPD (2) The effectiveness of developing LKPD (3) Students' response to the development of LKPD. The type of development applies Research and Development (R\&D) by choosing Thiagarajan's 4-D development model which consisted of defining, designing, developing, and disseminating. This research development carried out to the third step that Develop until knowing the feasibility and effectiveness of developing LKPD . Data collection was obtained from the results of validation of feasibility of development LKPD from the the pre-test and post-test activities, and the results of students' responses to the application of development LKPD that had been carried out. This results showed that (1) the average results of the material validation is $83 \%$, while, for the average results of the graph validation is $93 \%$, and for the average results of Language validation is $80 \%$ (2) for the effectiveness result seen from the pre-test and post-test activities obtained completeness results from $8 \%$ up to $81 \%$ with the result of $\mathrm{N}$-Gain is 0,81 which is included in the high category (3) based on the questionnaire responses of students who have been given show a percentage of 84\%. It showed that the Development LKPD Based on Provlem Based Learning and Critical Thinking on class XI Economic materiah are very feasible to be used.

\section{Keywords: Student Activities Sheet Based (LKPD), Problem Based Learning, Critical Thinking, and} Student Respons'.

\section{PENDAHULUAN}

Pendidikan menjadi salah satu alat dalam membentuk peserta didik yang cerdas dalam menghadapi permasalahan di lingkungan hidup, kemajuan teknologi dan informasi di era globalisasi, baik dalam ekonomi, industri kreatif dan budaya. Peserta didik sebagai calon generasi penerus bangsa, diharapkan dapat menyelesaikan permasalahan dengan bekali kemampuan menguasai teknologi informasi sesuai dengan era globalisasi, berkomunikasi yang memadai. Keterampilan, pengetahuan, sikap dan perilaku dapat digunakan menjadi dasar untuk mengamati pembentukan kemampuan peserta didik melalui pendidikan. Pembentukan kemampuan tersebut akan terwujud melalui pendidikan, apabila pengaplikasiannya sesuai dengan tujuan pendidikan. Adapun sasaran dari pendidikan Indonesia pada UndangUndang nomor 20 tahun 2003 Sistem Pendidikan 
Nasional, pasal 3, “tujuan pendidikan nasional adalah berkembanganya potensi peserta didik agar menjadi manusia yang beriman dan bertakwa kepada Tuhan Yang Maha Esa, berakhlak mulia, sehat, berilmu, cakap, kreatif mandiri, dan menjadi warga negara yang demokratis serta bertanggung jawab" dalam (Sani, 2014). Untuk mewujukan tujuan tersebut pemerintah melakukan upaya pengembangan pendidikan secara berkala melalui kurikulum pendidikan.

Kurikulum 2013 memiliki Standar Kompetensi Lulusan (SKL) mencakup pengetahuan, sikap, dan keterampilan. Adapun dasar dan prinsip penyusunan kurikulum 2013 mengacu pada Undang - Undang nomer 54 tahun 2013, "Standar kompetensi lulus adalah standar dari penggolongan kemampuan lulusan yang meliputi sikap, keterampilan dan pengetahuan. Standar kompetensi lulusan merupakan tolok ukur dalam pengembangan standar isi, standar proses, standar penilaian, standar pendidik, dan tenaga kependidikan, standar sarana dan prasarana, standar pengelolaan, dan standar pembiayaan pendidikan" dalam (Kunandar, 2014). Standar penilaian kompetensi pengetahuan dapat dilakukan dengan mengukur tingkat penguasaan peserta didik melalui karakteristik dari Taksonomi Bloom. Taksonomi Bloom ini terbagi menjadi dua tingkatan (1) kemampuan menghafal, (2) kemampuan memahami, (3) keterampilan menerapkan, termasuk kedalam tingkatan rendah, sedangkan untuk (4) kemampuan menganalisis, (5) kemampuan mengevaluasi, (6) kemampuan mencipta merupakan tingkatan tinggi. Dalam tingkatan tinggi ini ada dua tingkatan berpikir yaitu berpikir kreatif dan berpikir kritis.

Dewasa ini sangat perlu adanya penggunaan bahan ajar untuk proses pembelajaran. (Agustina, 2012) berpendapat bahan ajar selalu menjadi salah satu opsi pendidik sebagai alat bantu penyampaian kepada peserta didik dalam kegiatan proses pembelajaran belajar mengajar di kelas. Perlu adanya alat untuk mengimbangi teknologi informasi yang berkembang pesat dan berkembangnya ilmu pengetahua, maka terjadi adanya dorongan yang mengupayakan pembaharuan dan pengembangan proses pembelajaran. Ada upaya yang dapat dilakukan dari pesatnya kemajuan ilmu pengetahuan dan teknologi informasi yaitu pengembangan bahan ajar yang inovatif, menarik, dan menyenangkan. Pengembangkan pembelajaran mengutamakan kemampuan berpikir kritis peserta didik dengan menggunakan bahan ajar yang sesuai. Salah satunya adalah pengembangan Lembar Kegiatan Peserta Didik (LKPD) yang menggunakan model pembelajaran seperti PBL dan berpikir kritis dengan tujuan meningkatkan keterampilan berpikir peserta didik. Keberhasilan meningkatkan keterampilan tersebut dapat diamati dari adanya kenaikan hasil belajar peserta didik melalui model pembelajaran PBL dan berpikir kritis, dengan indikator interpretasi, analisis, inferensi, eksplanasi, dan evaluasi dari kegiatan pretest dan posstest, (Aprilian, 2018). Diharapkan peserta didik yang menerima pembelajaran dengan menerapkan indikator berpikir kritis dapat menyelesaikan studi kasusu sebagai atau personal untuk pembelajaran dalam kehidupan.
Berdasarkan dari hasil observasi berupa wawancara dengan guru Ekonomi kelas XI IIS dan peserta didik kelas XII IIS 3 di MAN Sidoarjo, peneliti menemukan hasil yang kurang sesuai dengan panduan bahan ajar, dimana sekolah memakai bahan ajar berupa LKPD yang kurang sistematis, kotekstual, inovatif, dan sesuai dengan kondisi lingkungan peserta didik di sekolah tersebut. Hasil dari penyelidikan awal yang telah dilaksanakan, peserta didik kelas XI IIS 3 MAN Sidoarjo menyatakan materi kerja sama ekonomi internasional merupakan materi yang sulit karena materinya membahas persoalan perekonomian yang cukup luas yaitu berkaitan dengan negara lain, banyak menggunakan istilah lembaga kerja sama internasional yang baru diketahui peserta didik dan bentuk kerja sama ekomomi internasional yang harus dihafal. LKPD yang digunakan sekolah belum disusun langsung oleh pendidik melainkan masih dari penerbit buku yang materi, isi, dan latihan soal dalam LKPD tersebut kurang sesuai dengan kondisi peserta didik yang aktif. LKPD yang beli dari penerbit buku isinya kurang tepat dan tidak sesuai dengan tujuan Kurikulum 2013, seharusnya di dalam bahan ajar mengandung kegiatan yang mengembangkan kemampuan peserta didik terutama dalam kegiatan berpikir kritis dalam mengahdapi sebuah permasalahan yang didalamnya terdapat kegiatan student center dan sesuai dengan lingkungan disekitar peserta didik.

Lembar Kegiatan Peserta Didik adalah suatu bagian dari bahan ajar berbentuk cetakan, berisikan materi pembelajaran, serta bahan evaluasi yang disajikan dengan berdaya guna dan ekonomis. Hal tersebut sesuai pendapat dari (Prastowo, 2013) yang mengatakan bahwa Lembar Kegiatan Peserta Didik ialah bahan ajar berbentuk lembaran-lembaran yang dicetakan, berisi materi, petunjuk penggerjaan tugas yang dikerjakan oleh peserta didik, dengan mencapai kompetensi dasar yang sesuai panduan.

(Arends, 2015) menyampaikan bahwa dengan model problem based leraning (pembelajaran berbasis masalah) dapat menguraikan pembelajaran yang membentuk keterampilan berpikir tingkat tinggi dan peserta didik dapat mengatasi permasalahan yang dihadapi, dapat menganalisis peran orang dewasa, dan dapat digunakan sebagai pembelajaran yang mandiri. Kesimpulannya keterampilan berpikir kritispada peserta didik dapat ditingkatkan dengan mengaplikasikan model pembelajaran berbasis PBL.

Tabel 1.1 Sintak Problem Based Learning Indikator

Orientasi kesesuaian masalah yang tersaji dengan materi dan studi kasus yang terdapat dalam LKPD terbukti kebenarannya

Terdapat langkah-langkah untuk mengorganisasi permasalahan pada peserta didik

Memberikan dorongan untuk mencari informasi, menyelidiki, dan mencari solusi sementara pada peserta didik

Menguraikan dan mempresentasikan hasil diskusi Menyelidiki dan menilai hasil diskusi

Sumber : (Sani, 2016) 
Menurut (Jhonson, 2014) "Berpikir kritis memungkinkan peserta didik untuk menemukan kebenaran di tengah banjirnya kejadian dan informasi yang mengelilingi mereka setiap hari”. Berpikir kritis merupakan suatu proses jelas dan terarah yang bertujuan untuk menyelesaikan masalah, membujuk, menarik sebuah kesimpulan sementara, menganalisis, dan melakukan penyelidikan ilmiah. (Amri, 2015) berpendapat berpikir kritis merupakan aktivitas kognitif yang dilaksanakan selama proses belajar dengan memanfaatkan nalar. Melalui berpikir kritis seorang peserta didik dituntut menguasai beberapa proses mental seperti mengamati, mengkategorikan, menyeleksi, dan menilai atau memberikan keputusan menurut.

\section{Tabel 1.2 Sintak Berpikir Kritis}

\begin{tabular}{|l|}
\hline \multicolumn{1}{|c|}{ Indikator } \\
\hline Kegiatan Interpretasi \\
\hline Kegiatan Analisis \\
\hline Kegiatan Inferensi \\
\hline Kegiatan Eksplanasi \\
\hline Kegiatan Evaluasi \\
\hline Kegiatan Self-regulation \\
\hline Sumber : (Aprilian, 2018)
\end{tabular}

Menurut pendapat (Musfiqon, 2012) respon merupakan interaksi yang dilakukan manusia dengan lingkungannya secara terencana untuk mencapai perubahan sikap, pemahaman, dan keterampilan pada diri sendiri. Menurut (Hamalik, 2010) dikatakan sebagai tanggapan berupa balasan terhadap stimulus yang diberikan pada suatu perilaku tertentu.

Diharapkan dari kegiatan penelitian yang bertujuan untuk mengetahui hasil kelayakan bahan ajar, peningkatan efektifitas hasil belajar dan respon dari peserta didik tentang LKPD berbasis Problem Based Learning dan Berfikir Kritis pada Materi Ekonomi Kelas XI dapat memberikan manfaat yang positif untuk berbagai pihak

\section{METODE}

Tipe penelitian yang dipilih adalah Research and Development (R \& D) maksudnya ialah penyelidikan yang akan memperoleh produk baru dari produk tertentu yang di kembangkan, produk baru yang diperoleh akan diuji keefektifannya dalam kehidupan masyarakat, dengan demikian produk baru yang dihasilkan diharapakan dapat bermanfaat baik sekarangi dan kehidupan seterusnya (Sugiono, 2017). Penelitian ini menggunakan model pengembangan yaitu Model 4-D dari Thiagarajan yang terdiri dari 4 tahapan yaitu Define (pendefinisian), Design (perancangan), Develop (pengembangan), dan Desseminate (penyebaran). Penelitian pengembangan ini dilaksanakan hingga tahapan yang ke ketiga yaitu Develop (pengembangan) untuk mengetahui kelayakan, efektivitas penelitian, dan respon.

Berikut ialah langkah penelitian dan penegmbangan Model 4D Thiagarajan :

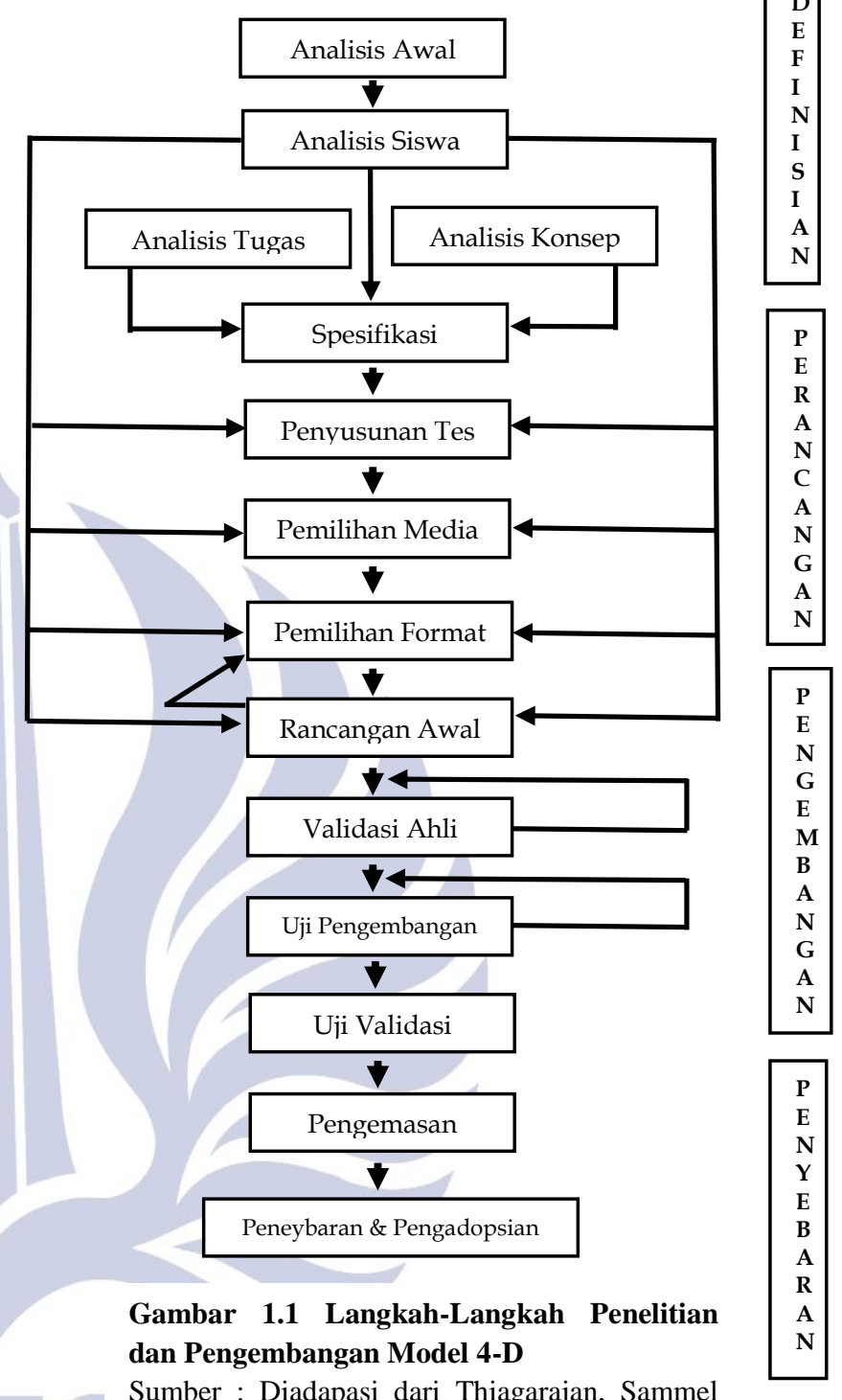

Sumber : Diadapasi dari Thiagarajan, Sammel dan Sammel (1974)

Prosedur penelitian diatas terbagi menjadi 4 tahapan, pertama adalah tahap defne (pendefinisian) yaitu tahap utama dalam penelitian yang akan menganalisis melalui 5 langkah yakni (1) analisis utama (awa), (2) analisis peserta didik, (3) analisis tugas, (4) analisis konsep, (5) analisis perumusan tujuan pembelajaran. Kedua adalah tahap design (perancangan) yaitu tahap menyusun draf perangkat pembelajaran melalui beberapa langkah seperti (1) penyusunan tes, (2) pemilihan media, (3) pemilihan format, (4) rancangan awal. Ketiga tahap develop (pengembangan) yaitu pengembangan bahan ajar yang akan memciptakan produk baru yang sudah ditelaah dan divalidasi oleh ahli untuk melihat hasil kelayakan bahan ajar dengan beberapa langkah seperti : (1) telaah dan validasi produk, (2) uji coba produk, (3) Simulasi perangkat pembelajaran. Keempat adalah tahap disseminate (penyebaran) yaitu setelah tersusunya LKPD berbasis PBL dan berpikir kritis, produk akan di uji cobakan pada secara luas, seperti ke lain kelas dan lain 
sekolah. Karena terbatas waktu dan dana, maka pada tahap ini tidak disebar luaskan.

Subjek uji coba penelitian ialah peserta didik kelas XI IIS 3 MAN Sidoarjo. Percobaan produk pengembangan memilih 36 peserta didik. Desain uji coba menerapkan pengujian terbatas di MAN Sidoarjo. PreExperimental dengan model One Group Pretest-Posttest Design (Sugiono, 2017) digunakan sebagai desain penelitian untuk mengetahui efektifitas LKPD yang dikembangkan. Berikut adalah gambar model One Group Pretest-Posttest Design :

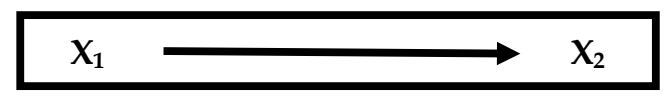

Gambar 1.2 Alur model One Group PretestPosttest Design

Sumber : (Sugiono, 2017)

Keterangan :

$\mathbf{X}_{1} \quad$ : Pre-Test diberikan sebelum proses belajar

$\mathbf{X}_{2} \quad$ : Post-Test diberikan setelah proses belajar

: Proses belajar

Model One Group Pretest-Posttest Design tahapannya yaitu diawali dengan kegiatan pre-tests sebelum peserta didik mendapat perlakuan pembelajaran, selama perlakuan menggunkan LKPD berbasis PBL dan berpikir kritis yang telah disusun. Selanjutnya setelah mendapatkan perlakuan pembelajaran barulah peserta didik diberikan post-test. Setelah memberikan pretestposttest dapat dilihat hasil dari keaadan sebelum mendapat perlakuan pembelajaran dan setelah mendapat perlakuan pembelajaran.

Penelitian ini menggunakan instrumen pengumpulan data sebagai berikut (1) melakukan telaah dan validasi bahan ajar seperti materi, kegrafikan dan bahasa yang dilakukan oleh para ahlinya untuk mengetahui kelayakan bahan ajar, (2) untuk mengetahui efektivitas LKPD selama pembelajaran maka melakukan kegiatan pretest dan posttest, (3) membagikan angket untuk melihat respon peserta didik terhadap LKPD yang telah diajarkan.

Metode analisis data dari pengembangan LKPD berbasis PBL dan berpikir kritis lembar telaah dan validasi menggunakan kriteria skala likert, sedangkan untuk analisis data efektifitas LKPD menggunakan skala ketuntasan hasil belajar dan skala penilaian $N$-Gain untuk melihat peningkatan hasil belajar, untuk analisis respon peserta didik menerapkan skala guttman sebagai jawaban soal dan melihat kriteria skala likert untuk melihat kelayakan dari respon peserta didik.

\section{HASIL DAN PEMBAHASAN} Hasil

Hasil dari penelitian pengembangan LKPD berbasis problem based learning dan berpikir kritis berdasarkan model 4D yang terbatas pada langkah ketiga yaitu develop (pengembangan). Langkah pertama yaitu define (pendefinisian): (a) analisis ujung (awal) diketahui bahwa sekolah telah menggunakan kurikulum 2013 dan menerapkan bahan ajar LKPD, namun ada kekurangan dari LKPD yang dipakai selama pembelajaran yaitu kurang sesuai dengan kurikulum 2013 dan tidak sesuai dengan kebutuhan peserta dalam memahami materi dan belum memenuhi kriteria berpikir kritis, (b) analisis peserta didik memilih kelas XI IIS 3 MAN Sidoarjo yang berjumlah 36 peserta didik, (c) analisis konsep yaitu pengembangan LKPD berbasis PBL dan berpikir kritis pada KD Kerja Sama Ekonomi Internasional, (d) analisis tugas peserta didik akan mengerjakan soal preteset sebelum proses belajar dan mengerjakan soal posttest setelah proses belajar selama pembelajaran berlangsung peserta didik akan menyelesaikan permasalahan mengenai kerja sama ekonomi internasional dalam sebuah artikel yang dikerjakan dengan berdiskusi dalam kelompok, (e) analisis tujuan pembelajaran pada pengembangan LKPD berbasis PBL dan berpikir kritis disesuaikan dengan $\mathrm{KD}$ dan indikator kerja sama ekonomi internasional.

Langkah kedua ialah design (merancang). Pada tahap ini isi materi dan desain LKPD disesuaikan dengan model yang dikembangakan yaitu pembeajaran berbasis masalah dan berpikir kritis dengan menyajikan permasalahan berupa artikel untuk dipecahkan oleh peserta didik. Pertanyaan untuk memecahkan permasalahan dalam artikel harus mengacu pada konsep problem based learning dan berpikir kritis. Selain artikel adapun pojok informasi serta gambar yang memberikan ilustrasi materi untuk mudahkan peserta didik memahami materi kerja sama ekonomi internasional. Gambar dan desain layout disesuaikan agar menarik dan memotivasi peserta didik untuk belajar. LKPD berukuran A4 $(21 \mathrm{~cm} \mathrm{x}$ $29,7 \mathrm{~cm})$.

Langkah ketiga ialah develop (pengembangan). Pada tahap ini draf LKPD yang dikembangkan telah disusun, kemudian ditelaah dua ahli yakni dari ahli materi dan ahli pembelajaran dimana draf tersebut dianalisis dan direvisi sehingga menghasilkan draf yang telah direvisi. Selanjutnya setelah merevisi draf LKPD, langkah selanjutnya adalah validasi ahli materi dan ahli pembelajaran untuk melihat kelayakan LKPD sebelum dilakukan uji coba lapangan. Setelah proses validasi, sebelum melaksanakan kegiatan pembelajaran, maka peserta didik akan diberikan soal prestest untuk dikerjakan. Setelah menerima pembelajaran menggunakan pengemabangan LKPD, peserta didik akan mengerjakan soal posttest untuk meihat apakah ada peningkatan hasil belajar pada peserta didik.

\section{Pembahasan \\ Kelayakan Lembar Kegiatan Peserta Didik}

Kelayakan LKPD berbasi PBL dan berpikir kritis pada KD kerja sama ekonomi internasional kelas XI IIS 3 MAN Sidoarjo yang diukur dari penilaian validasi para ahli. Validasi dinilai dua orang ahli yaitu ahli materi dan ahli pembelajaran.

Hasil validasi materi yang terdiri dari empat komponen penilaian dengan penilaian kelayakan isi sebesar $81 \%$ yang berkategori sangat layak, selanjutnya kelayakan penyajian bernilai sebesar $83 \%$ yang berkategori sangat layak, jumlah penilaian problem based learning sebesar $86 \%$ yang berkategori sangat layak, dan jumlah penilaian berpikir kritis sebesar $80 \%$ yang berkategori layak. Keempat komponen tersebut memiliki 
rata-rata sebesar $83 \%$ yang berarti LKPD berbasis PBL dan berpikir kritis berkategori sangat layak sehingga dapat diterapkan dalam pembelajaran ekonomi materi kerja sama ekonomi internasional. Hal tesrsebut sesuai dengan penelitian (Nur Aisyah Aini, Ahmad Syachruroji, 2017) menyimpulkan kualitas LKPD yang dikembangkan berkategori sangat baik dengan persentase 95,6\%, dan dari 2 ahli materi yaitu $100 \%$ dari ahli kegrafikan, dan 92,3\% dari ahli Bahasa sehingga sangat layak diterapkan dalam pembelajaran.

Hasil validasi kegrafikan terdiri dari tiga komponen yang dinilai yaitu jumlah penilaian ukuran LKPD dengan hasil sebesar $100 \%$ yang berkategori sangat layak, kemudian jumlah penilaian desain kover LKPD dengan hasil sebesar $90 \%$ yang berkategori sangat layak, dan jumlah penilaian desain isi LKPD dengan hasil sebanyak $88 \%$ berkategori sangat layak. Ketiga komponen tersebut memiliki rata-rata sejumlah $93 \%$ yang menyatakan LKPD berbasis PBL dan berpikir kritis sangat layak digunakan untuk pembelajaran di kelas. Hal tesrsebut sejalan dengan penelitian (Nur Aisyah Aini, Ahmad Syachruroji, 2017) menyimpulkan kualitas LKPD yang dikembangkan berkategori sangat baik dengan persentase 95,6\%, dan dari 2 ahli materi yaitu $100 \%$ dari ahli kegrafikan, dan 92,3\% dari ahli Bahasa sehingga sangat layak diterapkan dalam pembelajaran.

Hasil validasi bahasa terdapat enam komponen yang dinilai yaitu jumlah penilaian pesesuaian dengan perkembangan peserta didik dengan hasil sebesar $80 \%$, keterbacaan dengan hasil penilaian sebesar $80 \%$, kemampuan memotivasi dengan hasil penilaian sebesar $80 \%$, keterpaduan dan runtutnya alur berpikir bernilai sebesar $80 \%$, keselarasan kalimat dengan kaidah bahasa Indonesia bernilai sebesar $80 \%$, dan penggunaan istilah dengan hasil penilaian sebesar $80 \%$. Keenam komponen tersebut memiliki rata-rata sebesar $80 \%$, sehingga menyatakan LKPD berbasis PBL dan berpikir kritis berkategori layak digunakan dalam pembelajaran namun belum sempurna karena saran validator kalimat yang digunakan dalam lembar kegiatan peserta didik kurang efektif selain itu penulisannya masih banyak yang kurang sesuai Ejaan yang benar.

Total keseluruhan validasi yang telah dilaksanakan memiliki rata-rata sejumlah $85,3 \%$ yang artinya LKPD berbasis PBL dan berpikir kritis materi kerja sama ekonomi internasional sangat layak untuk dijadikan bahan aja dalam pembelajaran ekonomi. Hasil kevalidan suatu produk dinyatakan tidak layak apabila prosentase penilainnya kurang dari $61 \%$, akan dinyatakan layak apabila prosentase peniliannya anatara $61 \%$ sampai dengan $80 \%$, dan akan dinyatakan sangat layak apabila prosentase penilainnya antara $81 \%$ sampai dengan $100 \%$ (Sani, 2016).

\section{Efektifitas pengembangan LKPD berbasi PBL dan berpikir kritis pada KD kerja sama ekonomi internasional}

Berdasarkan hasil nilai dari pretest-posttest dari 36 peserta didik kelas XI IIS 3. Pada hasil pengerjakan soal pre-test sebanyak 33 peserta didik mendapatkan nilai rendah $\leq 75$, nilai terendah pada hasil pre-test sebesar 10 , artinya prosentase ketuntasan belajar sebesar $92 \%$ peserta didik kelas XI IIS3 tidak tuntas, sedangkan sebanyak 3 peserta didik memperoleh nilai tertinggi sejumlah 80 yang artinya mereka tuntas dalam mengerjakan soal pretest, prosentase ketuntasan belajarnya sebesar $8 \%$. Pada hasil post-test nilai terendah sebanyak 7 peserta didik mendapat sebesar 70 dengan porsentase $19 \%$ peserta didik dinyatakan tidak tuntas pada kegiatan posttest. Sedangkan sebanyak 29 dengan nilai tertinggi sebesar 100, dengan prosentase peserta didik memperoleh ketuntasan hasil belajarnya sebesar $81 \%$. Hasil tesebut sesuai dengan pandangan (Riduwan, 2016) yaitu keterampilan belajar peserta didik dapat diukur dari hasil penilain yang telah dikerjakan dengan penentuan kriteria ketuntasan belajar, peserta didik dikatakan tuntas jika memperoleh nilai dengan sebesar 75 sampai dengan 87 atau dinyatakan sangat tuntas apabila memperoleh nilai sebesar 88 sampai 100 .

Hasil kegiatan pre-test dan post-test memperlihatkan hasil belajar peserta didik secara signifikan mengalami peningkatan, hal tersebut dibuktikan dari nilai terendah post-test sebesar 10 sedangkan untuk nilai terendah post-test sebesar 70. Kemudian untuk nilai tertinggi pada kegiatan pre-test sejumlah 80 dan nilai tertinggi post-test sejumlahr 100 . Jumlah peserta didik yang tuntas dari post-test lebih banyak dari pada hasil kegiatan pre-test, sebanyak 29 peserta didik dinyatakan tuntas dalam kegiatan post-test, sedangkan pada pre-test yang tuntas hanya sebanyak 3 peserta didik. Kesimpulannya terjadi kenaikan dalam ketuntasan klasikal yang diperoleh, yang awalnya dari hasil pre-test sebesar $8 \%$ dan nilai pada kegiatan post-test sebesar $81 \%$. Hasil dari kegiatan pretest-postest untuk melihat efektifitas peserta didik diketahui dari hasil $\mathrm{N}$ Gain sebesar 0,81 yang berkategori tinggi, berarti terjadi peningkatan berfikir kritis pada efektifitas peserta didik yang diketahui dari nilai pre-test dan nilai post-test. Hal tersebut sejalan dari hasil penelitian (Sry Astuti, Muhammad Danial, 2018) Kemampuan berpikir kritis terjadi peningkatan bernilai rata-rata $\mathrm{N}$-Gain sebesar 0,824 yang berkategori tinggi.

Respon peserta didik terhadap LKPD berbasis PBL dan berpikir kritis pada KD kerja sama ekonomi internasional

U Berdasarkan hasil rekapitulasi respon peserta didik menunjukan bahwa pengembangan LKPD berbasi PBL dan berpikir kritis memudahkan sekaligus membantu peserta memahami materi kerja sama ekonomi internasional dengan sangat baik karena sebesar $86 \%$ peserta didik mengakuinya. Pada kelayakan penyajian peserta didik menyatakan setuju dengan ketertarikan, kesenangan serta menyatakan bahwa LKPD berbasis PBL dan berpikir kritis mampu memotivasi peserta didik selama pembelajaran. Mengenai kelayakan, peserta didik sangat setuju dengan memilih bahasa yang ringan untu dimengerti serta huruf yang terbaca, namun untuk istilah yang terdapat dalam materi maupun artikel sulit dipahami karena hanya sebanyak 25 peserta didik atau sebasar $69 \%$ mengakui istilah tersebut mudah dipahmi. Sedangkan untuk kelayakan kegrafikan menurut peserta didik 
tampilannya sudah bagus, hanya saja untuk warna dan gambarnya masih harus diperbaiki karena hasil prosentasenya tidak mencapai $80 \%$, namun dalam keseluruhan kelayakan penyajian sangat baik. Kesimpulannya respon dari peserta didik terhadap pengembangan LKPD berbasis PBL dan berpikir kritis berkategori sangat layak dengan jumlah rata-rata penilaian sebesar $84 \%$. Hal tersebut sejalan dengan hasil penelitian dari (Nur Aisyah Aini, Ahmad Syachruroji, 2017) sedangkan, untuk respon peserta didik didapatkan hasil dengan persentase $98,4 \%$ berkategori sangat baik.

\section{PENUTUP \\ Simpulan}

Berdasarkan hasil penelitian dari pengembangan

LKPD berbasi PBL dan Berpikir Kritis pada pada KD kerja sama ekonomi internasional di kelas XI IIS 3 MAN Sidoarjo, kesimpulannya sebagai berikut: (1) dari hasil validasi kelayakan materi, bahasa, kegrafikan menyatakan pengembangan bahan ajar sangat layak diterapkan dalam proses belajar di kelas XI IIS 3 MAN Sidoarjo, (2) dari hasil pretest-posttest yang dikerjakan peserta didik menyatakan bahwa bahan ajar memiliki efektifitas dalam hasil belajar peserta didik, (3) dari hasil respon yang diisi oleh peserta didik kelas XI IIS 3 MAN Sidoarjo menunjukan bahwa pengembangan bahan ajar menarik untuk digunakan dalam pembelajaran ekonomi pada KD kerja sama ekonomi internasional.

\section{Saran}

Diharapkan kedepannya pengembangan LKPD ini dapat diaplikasikan pada KD lain yang sesuai dengan pengembangan bahan ajar, disusun lebih kreatif dalam penataan lay out dan penyusunan materi dengan memilih kalimat yang efektif dan mudah dipahami, dan ditambah glosarium untuk memudahkan peserta didik memahami istilah sulit dalam materi maupun artikel.

\section{DAFTAR PUSTAKA}

Agustina, N. (2012). Efektifitas Pengembangan LKS Berorientasi Problem Based Learning untuk Melatihkan Keterampilan Berpikir Kritis Pada Materi Kebijakan Moneter Kelas XI. Pendidikan Ekonomi, 01 .

Amri, S. (2015). Implemetasi Pembelajaran Aktif dalam Kurikulum 2013. (E. K. Ersaela, Ed.). Jakarta: Prestasi Pustakarya.

Aprilian, I. R. A. (2018). Pengembangan Lembar Kegiatan Siswa Berbasis Problem Based Learning untuk Meningkatkan Berpikir Kritis pada KD Masalah Pokok Ekonomi Dalam Sistem Kelas X MIPA SMAN 1 Gedangan. Pendidikan Ekonomi, 6.

Arends. (2015). Problem Based Learning.

Hamalik. (2010). Psikologi Belajar Mengajar. Bandung: Sinar Baru Algesindo.

Jhonson, E. B. (2014). Contextual Teaching and Learning: Menjadikan Kegiatan Belajar Mengajar Mengasyikan dan Bermakna. Bandung: Penerbit Kaifa.

Kunandar. (2014). Penilaian Autentik (Penelitian Hasil Belajar Peserta Didik Berdasarkan Kurikulum 2013) (Ketiga). Jakarta: PT Raja Grafindo Persada.

Musfiqon. (2012). Pengembangan Media dan Sumber Pembelajaran. Jakarta: PT. Prestasi.

Nur Aisyah Aini, Ahmad Syachruroji, N. H. (2017). Pengembangan LKPD Berbasis Problem Based Learning pada Mata Pelajaran IPA Materi Gaya. Pendidikan Dasar.

Prastowo, A. (2013). Panduan Kreatif Membuat Bahan Ajar Inovatif. (D. Wijaya, Ed.) (V). Jogjakarta: DIVA Press.

Sani, R. A. (2014). Pembelajaran Saintifik untuk Implementasi Kurikulum 2013. (Y. S. Hayati, Ed.) (Pertama). Jakarta: PT bumi Aksara.

Sani, R. A. (2016). Inovasi Pembelajaran (IV). Jakarta: PT Bumi Aksara.

Sry Astuti, Muhammad Danial, and M. A. (2018). Pengembangan LKPD Berbasis PBL (Problem Based Learning) untuk Meningkatkan Keterampilan Berpikir Kritis Peserta Didik Pada Materi Keseimbangn Kimia. Chemistry Education Review, 1.

Sugiono. (2017). Metode Penelitian Kuantitatif, Kualitatif, dan $R \& D$. Bandung: Alfabeta.
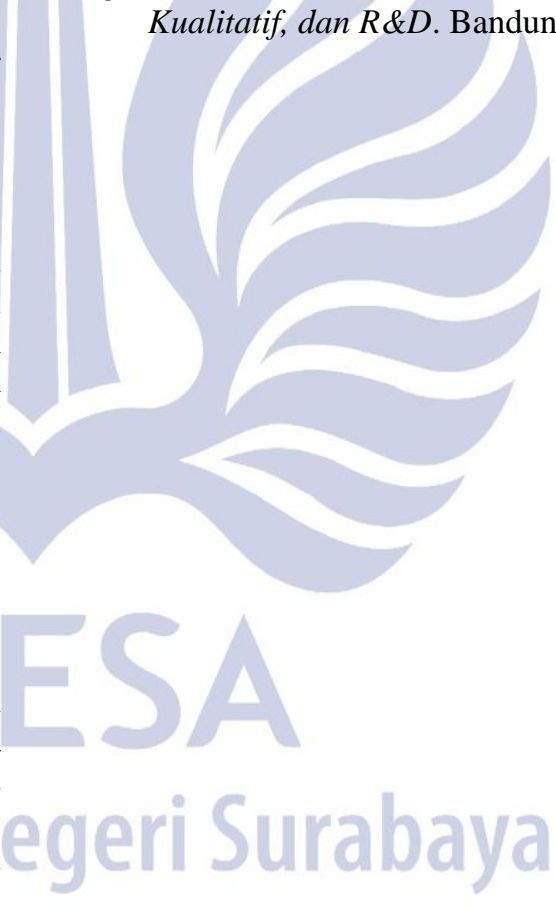